This item was submitted to Loughborough's Research Repository by the author.

Items in Figshare are protected by copyright, with all rights reserved, unless otherwise indicated.

\title{
Lost in plain sight: revealing central flow process in Christaller's original central place systems
}

PLEASE CITE THE PUBLISHED VERSION

https://doi.org/10.1080/00343404.2020.1772965

\section{PUBLISHER}

Taylor \& Francis (Routledge)

\section{VERSION}

AM (Accepted Manuscript)

\section{PUBLISHER STATEMENT}

This is an Accepted Manuscript of an article published by Taylor \& Francis in Regional Studies on 25 June 2020, available online: http://www.tandfonline.com/10.1080/00343404.2020.1772965.

\section{LICENCE}

CC BY-NC-ND 4.0

\section{REPOSITORY RECORD}

Taylor, Peter J, and Michael Hoyler. 2020. "Lost in Plain Sight: Revealing Central Flow Process in Christaller's Original Central Place Systems”. Loughborough University. https://hdl.handle.net/2134/12287360.v1. 


\title{
Lost in plain sight: Revealing central flow process in Christaller's original
}

\section{central place systems}

\author{
Peter J. Taylor and Michael Hoyler
}

Peter J. Taylor (corresponding author)

crogfam@gmail.com

Geography and Environmental Sciences, Northumbria University, Newcastle upon Tyne, UK

ORCID https://orcid.org/0000-0003-4346-6364

Michael Hoyler

M.Hoyler@lboro.ac.uk

Geography and Environment, School of Social Sciences and Humanities,

Loughborough University, Loughborough, UK

ORCID https://orcid.org/0000-0003-2683-6175 


\section{Lost in plain sight: Revealing central flow process in Christaller's original central place systems}

Abstract

Christaller's central place theory famously conceptualizes local external urban relations (town-ness) while neglecting non-local connections characterized as central flow theory (city-ness). In this paper, we advance the study of central flow theory by revealing its existence within the foundation text of central place theory. We systematically separate town-ness and city-ness in Christaller's original data on 1920s southern Germany to estimate the balance between the two processes for different urban places. We find that city-ness dominates townness in leading cities and show the severe limitations of focusing on just one urban external relation in urban and regional studies of settlement systems.

Keywords: central place theory, central flow theory, urban external relations, settlement systems, primacy, Christaller

JEL: R0, R1, R12 


\section{INTRODUCTION}

Study of the external relations of cities has a chequered history. Commonly ignored by urban scholars and relegated to niche status, nevertheless it became a major research topic in urban and regional geography from the late 1950s through to the 1970s under the auspices of central place theory (Berry \& Pred, 1965; Bourne \& Simmons, 1978). The initial stimulus was a rediscovery of Walter Christaller's (1933) Die zentralen Orte in Süddeutschland in which an economic theory of settlement patterns was developed and empirically illustrated for towns and cities of southern Germany. This central place theory was deemed to be a critical building block of the new Geography as 'spatial science' (Bunge, 1962) and Christaller's work became more widely accessible in the Anglophone world through publication of an English translation in 1966. But interest in central place theory rapidly waned with the demise of the spatial science paradigm (van Meeteren \& Poorthuis, 2018, pp. 122-124). However more recently the growth of research on world/global cities has renewed interest in the external relations of cities (Taylor, 2001; Taylor \& Derudder, 2016).

Key founders of the world cities literature brought back central place theory to try and make sense of cities in globalization. For instance, Friedmann (1986) devised world city hierarchies reminiscent of national urban hierarchies as derived from central place theory (Berry \& Horton, 1970) as part of his 'world city hypothesis'. Hall (2002) was even more explicit in using Christaller's urban hierarchy 'for a global age'. But this linking of the traditional theory to inter-city 
relations in contemporary globalization has been problematic (Saey, 2008). Analyses of the external relations of world cities have deployed a network methodology rather than a simple hierarchy (Taylor, 2004; Taylor \& Derudder, 2016). However this should not be interpreted as a way of side-lining central place theory from urban research. Rather the network approach has been characterized as 'central flow theory', not to replace central place theory but to complement it (Taylor, Hoyler, \& Verbruggen, 2010). The argument is that central place theory describes local external relations of urban places (hinterlands) while central flow theory describes their non-local external relations (hinterworlds). Thus urban external relations consist of two distinctive processes producing different spatial arrangements, local hierarchical patterning and non-local network connectivity. All urban settlements have developed through both processes, which are termed town-ness and city-ness respectively. Therefore in this process-led way of considering an urban place, the question as to whether a settlement is a town or a city is not meaningful: all urban places combine both processes, town-ness and city-ness. Of course, the larger the urban place there will tend to be proportionally more city-ness (Taylor \& Derudder 2016, p. 43); non-local inter-city relations may become dominant but important local provisioning still exists in the 'downtowns' of all large urban places.

Being derived from studies of cities in globalization, it follows that in contrast to central place theory, the development of central flow theory is relatively recent (Taylor, 2007; Mayhew, 2009). The foundation text (Taylor et al., 2010) has been integrated into urban economics (Glaeser, Ponzetto, \& Zou, 2016, p. 21) and has been employed for understanding city networks in a variety of contexts: for 
instance, Doran and Fox (2016) using mobile phone data, Derudder and Taylor (2018) using data on non-governmental organizations, maritime services and media, Xu, Zhen, Qin, Wang, \& Wang (2019) for analysing the urban catering industry, and Taylor (2019) as a means of comparing ancient and modern city networks. The latter utilizes the generic nature of central flow theory as originally emphasized in Taylor et al. (2010). Thus although stimulated by contemporary urbanization, central flow theory, like central place theory, should be present in all urbanization. And this includes Christaller's original study region: southern Germany in the 1920s.

The intention of this paper is to contribute to extending the range of central flow theory empirical applications but with a critical ontological purpose: to show the existence of central flow theory (city-ness process) within the original data Christaller used to illustrate his central place theory (town-ness process). From the beginning there has been criticism of Christaller's (1933) theory and analysis for the very restrictive assumptions in his economic reasoning (Ullman, 1941; Getis \& Getis, 1966) but there is one fundamental assumption that is barely recognized in the literature. Christaller assumes that his settlement systems are not porous: they are empirically treated as separate systems; there are no relations outside the system. This basic assumption is never explicitly stated by Christaller and therefore not justified by him as with the economic and spatial assumptions he uses. And yet ignoring porosity is patently perverse: no citysystem is an island, spatial interactions occur in, through and between citysystems. What we have here is a convenient assumption that serves the needs of his empirical analyses, simplifying by disregarding a complicating feature. 
Central flow theory is that complicating feature. In this study we retrieve this hidden process from within Christaller's original data. The basis of our argument is that if there are indeed two processes in urban external relations then the corollary is that these will both be present in the data Christaller collected for illustrating central place theory in his southern Germany case study. Therefore the measures of the importance of urban places he derives from his data should encompass both town-ness and city-ness. For instance, he provides measures of Munich as a very important central place with a large hinterland but Munich had important links beyond its hinterland to other parts of Germany and central Europe. Such links are outside the scope of his central place theory and therefore do not feature in Christaller's analyses and interpretations. In this paper we reanalyse Christaller's (1933) data to measure the central flow process that has previously been overlooked by Christaller. We consider this vital omission in Christaller's pioneer work, and in its subsequent diffusion in geographical settlement research, to be the reason why central flow theory has only relatively recently been identified in urban and regional studies.

We develop a way of analysing Christaller's original data to separate town-ness and city-ness so as to estimate the balance between the two processes for different urban places. In his large-scale study of settlements in southern Germany Christaller was limited in the data he had at his disposal; notably economic statistics are missing. Thus he relied greatly on demographic and areal statistics of places but he did find one set of data that indicated connectivity, numbers of telephones in places. In this way he is introducing flows into his 
interpretation but only within his city-systems. In our search for flows beyond his city-systems we focus on this part of his empirical research. As a data source for central flow theory, such place-based telephone data are, of course, a very limiting set of information but we are able to make estimates comparing townness and city-ness. For instance, we compute that for an urban place as important as Munich we find city-ness dominates town-ness in the city's external urban relations. However, results such as this are only indicative; there can be no detailed modelling to provide precise predictions. Nevertheless our results are clear-cut in showing the existence of central flow theory within Christaller's original data, as per our ontological purpose.

The paper is divided into three parts. First, we explore the origins of central place theory in earlier studies of the spacing of cities where Christaller's imposition of a non-porosity assumption never featured. Second, we describe Christaller's data and present analyses that show the existence of central flow process alongside his central place process. In a final section, we assess the importance of our reworking by showing the severe limitations of focusing on just one urban external relation, while ignoring the other.

\section{THE SPACING OF CITIES}

In discussing his creation of central place theory, Christaller (1966/1972, p. 606) describes how he moved settlement geography from a focus on the siting of cities to the spacing of cities. The former approach explained urban locations through specific topographic attributes of sites, whereas he brought in economic theory 
to produce general laws in settlement geography. In fact, Christaller (1933/1966, pp. 2-3) begins his classic thesis Central Places in Southern Germany by briefly reviewing past studies that deal with distances between towns, and references founding fathers of German geography - Ritter, Ratzel and Hettner - to justify his 'new' focus on places and their hinterlands. But he notes that these studies dealt with 'traffic routes' - they were more about the flows than the places something he changed in his search for valid economic laws. ${ }^{1}$

This alternative geographical tradition of studying the spacing of cities is, perhaps, best represented by Reclus's (1905/2013, p. 166) treatment of geometric positioning of cities by 'travel distances' producing a 'network of settlements'. ${ }^{2}$ Rather poetically he describes it thus: 'On almost all the high roads the rhythm of cities follows the same plan - a sort of natural cadence regulating the progress of men, horses, and carriages' (Reclus, 1895, p. 251). Although he refers to 'local endowment' there appears to be no concept of city hinterland in his work (Reclus, 1905/2013, p. 170). Hence instead of grounding settlement locations in the economic laws of competition, Reclus (1895, p. 253) uses cooperation - mutuality between cities - as central to his argument. Thus Christaller's central place theory, and specifically its promotion as the cornerstone of the 'new Geography' of the 1960s (Bunge, 1962), can be interpreted as a foreclosing on the study of cities' cooperating in networks. This left city competition through hierarchies as the only form of urban external relations being researched, which endured even after the demise of the theory's importance from the 1980s (Taylor, 2009). 
A case in point is Friedmann's (1986) description of a 'world city hierarchy'. He had previously used central place hierarchies in his national development planning studies and he scaled up this framework to the global level. His iconic portrayal of New York, London and Tokyo on top of three continental-scale urban hierarchies became the standard way in which cities were viewed within globalization for about two decades (Taylor, 2004). And this despite Thrift's (1986) contemporaneously showing that the geography of globalization involved a single financial market serviced by the three cities representing time-zone mutualities rather than spatial-hinterland competition. The latter focus was partially countered by Sassen's (1991) global city thesis that dealt with both hierarchy and mutuality between these same three cities but with a continued emphasis on place rather than flows. However, using her global city formation process, Castells (1996) turned this around as cities in a global space of flows; in his Network Society it is flows producing cities rather than cities generating flows as implied by Sassen (Allen, 1999). In empirical terms this difference is indicated by the way that flows are modelled. In central place theory and related studies the links between settlements are vertical, connections are only between places from different service levels. In central flow theory all connections between settlements are considered, enabling horizontal links between settlements at high service levels to be prominently featured. The latter approach opened the way for both (i) interpretation of competition and cooperation in settlement systems (Taylor, 2012) and (ii) the use of network analysis to study cities in globalization (Taylor, 2001). 
The world city network has been modelled as an interlocking network with cities as service centres for global capital - financial, professional and creative service firms enabling economic globalization through work done in their offices throughout cities across the world (Taylor, 2001, 2004). In contradiction to Hall (2002), this was self-evidently not a central place model. Instead it has formed the framework for the introduction of central flow theory to complement central place theory (Taylor et al., 2010). Although developed as a means of describing inter-city relations in contemporary globalization, it is presented as 'theory' to authorize use generically, to understand inter-city relations in different historical contexts (Taylor, 2013, 2019; Verbruggen, 2011; Derudder \& Taylor, 2018). Thus central flow theory is heir to Reclus's 'spacing of cities', reversing Christaller's removal of mutualities from the study of external relations of cities. With recognition of two generic processes, we would expect the central flow process to have operated in Christaller's empirical case study, southern Germany in the 1920s.

\section{A NEW REWORKING OF CHRISTALLER'S DATA}

According to Parr (1980, p. 141) 'One of the disappointing features of central place theory has been its frequent inability to describe actual urban systems'. This is even the case where settlement systems adhere closely to the assumptions of the theory. Parr goes on to identify the restrictive nature of Christaller's modelling as the problem and supports a more flexible approach to applying the central place model. Specifically he proposes an interesting developmental approach to replace the 'static' (cross-sectional analysis at one 
point in time) nature of the theory. Particularly interesting from our perspective is that he uses Christaller's original data on settlements in southern Germany to further his argument.

Parr's research is about Christaller's hierarchical ordering of settlements, the frequency of places at different levels. He provides a reworking of Christaller's data in conjunction with revisions in theory as a means of improving the predictive capacity of the model. Thus he stays within the parameters of the theory; in contrast we are explicitly using predictive discrepancies to inform settlement ordering from outside the theory. We argue that in the upper echelons of the settlement hierarchy the size of settlements depends on more than the hinterland market. Specifically goods and services of the leading city in a settlement system provisions both local hinterland and non-local relations with other cities. This dual market servicing - both inside and outside the settlement system - is what we mean by central flow theory complementing central place theory (Taylor et al., 2010). It follows that the leading city should provide more goods and services than predicted by central place theory alone. Put simply there is an expectation of primate tendencies in settlement systems and this is what we are looking to examine for the first time in our new analysis of Christaller's original data.

\section{Christaller's data}

Christaller (1933/1966) divides southern Germany into five L-systems of settlements centred on Munich, Nuremberg, Stuttgart, Strasbourg and Frankfurt. 
Table 1 lists the information provided for each system, which we have divided into three types of quantitative material.

First, there are the theoretical deductions for L-systems in general. This is provided by the $\mathrm{k}=3$ marketing model from which expected values and frequencies for four key measures at each hierarchical level of places can be derived. Second, there are different categories of empirical information. Christaller suggests increasing types of goods and services by hierarchical level of places but only supplies informed 'guesstimates' of numbers of services. Thus this provides an idea of increasing specialization at higher levels but not actual quantities of servicing and so is not of direct interest for modelling. But he does collect two sets of data that are central to modelling: population of places from the German census (1925) and numbers of telephone connections in places gathered from telephone directories (1931). From the former Christaller calculates population averages for places and the areas they service, plus two measures involving telephone connections. Telephone density measures places having more or less connections for their populations compared to regional norms, and from which centrality for a place is derived as more than expected. Third, the latter is then used to determine central types of places, which constitute the hierarchy of settlements in the L-system. Christaller identifies seven levels of central place types within the L-system: L, P, G, B, K, A and M. One very important feature of Christaller's five L-systems is that they do not conform to national boundaries. Only two of his settlement systems, Stuttgart and Nuremberg, are wholly within Germany (i.e. as of 1925). For the other three, 
Munich, Strasbourg and Frankfurt, although P-places and G-places are listed from outside Germany there are no data on population or telephone connections, and therefore no measures of telephone density or centrality for non-German cities. This was very important for Parr's (1980) study since it focuses on numbers of places at different settlement levels and he tackles this issue in line with his research purpose. As will be seen below, this problem is largely avoided in this study because the preferred model uses averages across place types that can be assumed to provide reasonable estimates for the whole settlement system since there is no reason to think that German and non-German places differ significantly within hierarchical levels.

However we do omit one of Christaller's L-systems from our analyses. The Strasbourg system is problematic on two counts. First, the leading city itself is outside Germany and therefore is missing essential data. Second, and in any case, this leading city is not itself identified as an L-place. Since our concern is investigating city primacy, the lack of an L-place disqualifies this settlement system. Therefore our analyses cover just the four L-systems of Munich, Stuttgart, Nuremberg, and Frankfurt. Their primate tendencies for three of Christaller's measures are shown in the traditional way as the ratio of largest city to second largest city in Table 2. In the original introduction of the primate city concept (Jefferson, 1939) primacy was identified by ratios above two and this rather low threshold is easily achieved in all cases in Table 2 . This does provide clear evidence that there appear to be strong primate tendencies in the original evidence Christaller marshalled to illustrate his central place theory. This is what 
we explore further as indicating the existence of a central flow process operating alongside the central place process in Christaller's data.

\section{Central flow process in telephone connections}

Although all showing definite primate tendencies in Table 2, the three ratio measures do vary, with population showing least primacy and centrality the most. In our analyses below we have decided to use the data behind the middle ratio, numbers of telephone connections, for two reasons. The first derives from our interest in the central flow process: telephone connections are the facilitating technology for spaces of flow and therefore should reflect both intraand extra-system connections. The information Christaller has assembled remains an attribute measure (frequency at a place) rather than ideally a relational measure (origin and destination links) but nevertheless it describes the enabling of the links. Further it is the key mechanism in the operation of marketing practices at this time: Christaller (1933/1966, p. 143) says that 'nothing today is as necessary' so that the telephone becomes 'a kind of common denominator' within his analyses. The second, more practical, reason is a matter of ease of interpretation; the number of connections is simply easier to comprehend as a measure searching out primacy in comparison to Christaller's related concept of centrality.

The main problem with the results in Table 2 is that they are based on ratios derived from just pairs of cities thereby using hardly any of the wealth of data on southern German L-systems that Christaller provides. A method reliant on just 
two cities is a blunt technique with findings that are not necessarily that robust. We know that individual settlements can be subject to various particular influences outside the central place model and they may distort patterns of primacy. The data we use is illustrated in Table 3. Since our concern is to find central flow process that is concentrated in the upper echelons of the settlement hierarchy, we use only telephone connection data from K-places upwards. These have typical populations of just 4000 and may be reasonably thought to engage in little or no extra-system links. The resulting five levels of settlements include 367 German urban places as the basis for analysis, specifically represented as average frequencies for each level.

The analysis is laid out in Table 4 . Starting with theory, we use the $\mathrm{k}=3$ central place model where market areas increase by multiples of three up through the service levels. However every central place provides goods and services for its designated level and for each level below and therefore the total market of goods and services increases accordingly (Christaller, 1933/1966, p. 19). For instance, the L-place provides L-level goods and services to its full hinterland, plus P-level goods and services to its immediate P-market area, and so on through smaller market areas centred on the L-place. Unlike the change coefficients for market areas (all 3 by definition), for total markets the increase between levels are found to be variable, decreasing from four $(\mathrm{B} / \mathrm{K})$ to just above three $(\mathrm{L} / \mathrm{P})$.

For the empirical assessment, averages from Table 3 are used to provide actual change coefficients between levels. Focusing on the overall averages, in contrast to the theory these coefficients show a gradual increase in the size of the change 
coefficient. And there is a notable jump from P-level to L-level. This is clearly confirmed in the final difference comparison of the empirical to the theory where the observed is more than twice the size of the predicted for the L/P coefficient. The systematic increase in coefficients with levels and the concentration at the top level is exactly what would be expected with a central flow process augmenting central place servicing.

The change coefficients for the four L-systems (Table 4 (ii)) show some variation from the average and this is in part due to less robustness: $\mathrm{P} / \mathrm{G}$ and, especially, L/P coefficients for individual L-systems are based upon relatively low numbers (Table 3). Only eight P-places are compared to the four L-places and for the Munich settlement system there is just one P-place. In this latter case the analysis is identical to the traditional primate ratio employed in Table 2. In order to take the analysis forward more robustly we focus on the change coefficient across all the levels: L/K. This means that the purported primate city in each system is compared to averages derived from $239 \mathrm{~K}$ cities (Table 3 ). The change coefficient for this big step from $\mathrm{K}$ to $\mathrm{L}$ is derived from the total markets in Table 4 (i) as $48,400 / 400=121$.

The method used to estimate the central flow process contribution to an L-city's telephone connections is set out in Table 5 for each L-system. The empirical input is listed in the first two columns: the actual numbers of telephone connections and the average numbers for K-places in each system. The variations in the latter indicate different levels of telephone uptake suggesting slight differences in economic development. These K-place numbers are 
multiplied by the change coefficient (121) to predict L-place numbers of connections in each system as a central place process. This is presented as a percentage of the actual number of telephone connections in the four L-places and it can be seen that there is quite a large range here: $29 \%$ to $59 \%$. The central flow process is then calculated as the residual, the number of telephone connections not accounted for by central place theory. Percentages are therefore the inverse of the latter: $41 \%$ to $71 \%$.

The results in Table 5 show that overall for these leading cities of settlement systems the enabling technology (i.e. telephone connections) was slightly more engaged in external-system linkage than internal-system linkage. What this means is that the connectivity of these L-places is not simply an effect of the sizes of the market in their settlement system, rather the wider market of inter-city relations is at least as important.

This is a big claim, which we argue, is plainly supported by the results in Table 5 . However our method of measuring the central flow process, as the residual after taking the central place process into account, requires further scrutiny. It assumes that all the differences listed in Table 5 are the result of satisfying market demand outside each L-system. Hence we are overlooking other processes that might be enhancing telephone connections in the L-cities. This will remain a problem because our data source does not enable further refinement of the findings. Also there is no clear indication in Christaller's text of what these additional processes might be, agglomeration effects related to city size seem likely possibilities. Thus it is instructive that Christaller chose southern 
Germany to illustrate his theory, it being less industrial than other parts of Germany in the 1920s. With this in mind our understanding of the results from Table 5 is as follows. First, as well as the data limitations it should be noted that we do not use any modelling techniques, and yet our simple comparative method is, we would argue, sufficient for our research aim: finding a central flow process. Still, the specific values we have computed, the central flow estimates, are strictly the maximum possible level of external links. Nevertheless as notional estimates they are very clearly supported by the pattern of results generated. The broader picture they present based upon clear variations and contrasts between the L-systems strongly supports the credibility of our findings. The differences between the two processes are clear-cut as are the divergences between the four L-systems. In terms of the latter, Munich has by far the largest central flow percentage, followed by Frankfurt, and with Nuremberg and Stuttgart both having slightly more central place process than central flow process. This ordering is exactly in line with central flow theory expectations: the more important cities are least dependent on their local system's markets.

As a major German city in the 1920s (Blotevogel, 2002) it is entirely feasible that Munich's telephone connections were more due to extra-system process than intra-system processes as our results clearly demonstrate. In fact Christaller (1933/1966, pp. 157-158, 171) does briefly recognize this when he identifies Munich as an 'RT-place' above other L-places in southern Germany; these are specific central places at a level between L-places and 'world cities or national capitals' which he designates as R-places (p. 157). However this fleeting glimpse at external links beyond the Munich L-system is not followed up by Christaller. It 
is outside the scope of his empirical analyses so that the section of his text on the Munich L-system entitled 'Results' (pp. 185-188) makes no mention of RT status.

\section{CONCLUSION}

The incorporation of central place theory into the new Geography in the 1950s and 60s resulted in its research reincarnation as national urban systems (Bourne \& Simmons, 1978). System-ness was empirically depicted through city-size rankings, countries were contrasted as complex urban systems integrated through central place process versus simple settlement structures, dominated by one leading 'primate city' (Berry, 1961). But, as we have seen, in his central place research, Christaller was no respecter of state boundaries (see also Christaller, 1950). ${ }^{3}$ In this study we have taken this difference between Christaller's research and that of his later disciples a stage further. We have shown that city primacy exists in Christaller's study by comparing the top two cities in four of his settlement systems (see Table 2). It seems primacy in the very first central place study has been lost in plain sight, by modelling that precludes primacy. ${ }^{4}$ In our research, primacy indicates the existence of a second external urban relation process, central flow theory.

This paper has had a straightforward purpose. Starting with the argument that external urban relations take two forms, local town-ness and non-local city-ness, we note that it is the former that has been primarily studied, traditionally represented by central place theory. The origin of the latter in Christaller's 1933 doctoral thesis includes detailed empirical specification of central places for his 
study region, southern Germany. But if there are two processes of external relations then the non-local relations, which we call central flow theory, should be present within Christaller's large data set. We have devised a way of separating out central place and central flow processes and have shown that the latter relatively increases in line with Christaller's urban hierarchy. And as expected, central flow process is especially important in the four leading cities Munich, Frankfurt, Stuttgart and Nuremberg, cities that remain highly connected externally in contemporary globalization (Hoyler, 2011).

Our new approach to reworking Christaller's data has demonstrated that in studying urban and regional systems central place theory alone is not enough, it needs to be supplemented by central flow theory. In other words, such spatial organization is inherently porous, and today it is significantly global. The

porosity has sometimes been recognized (e.g. Bourne, 1975, p. 16; Bourne \& Simmons, 1978, p. 19) but the scale of the problem is not appreciated and therefore not fully addressed in urban and regional research. ${ }^{5}$ We have provided a unique analysis that shows the importance of central flow process by quantifying its effect. The results are very clear-cut: our reworking of Christaller's data has validated central flow theory strategically where central place theory first began.

\section{DISCLOSURE STATEMENT}

No potential conflict of interest was reported by the authors. 


\section{REFERENCES}

Allen, J. (1999). Cities of power and influence: settled formations. In J. Allen, D. Massey, \& M. Pryke (Eds.), Unsettling cities: Movement/settlement (pp. 181-218). London: Routledge.

Batty, M. (2013). The new science of cities. Cambridge, MA: The MIT Press.

Berry, B. J. L. (1961). City size distributions and economic development. Economic Development and Cultural Change, 9(4), 573-588. https://doi.org/10.1086/449923

Berry, B. J. L., \& Pred, A. (1965). Central place studies: A bibliography of theory and applications. Philadelphia: Regional Science Research Institute.

Berry, B. J. L., \& Horton, F. E. (1970). Geographic perspectives on urban systems. Englewood Cliffs, NJ: Prentice Hall.

Blotevogel, H. H. (2002). Städtesystem und Metropolregionen. In Institut für Länderkunde (Ed.), Nationalatlas Bundesrepublik Deutschland. Bd. 5: Dörfer und Städte (pp. 40-43). Heidelberg: Spektrum Akademischer Verlag.

Bourne, L. S. (1975). Urban systems: Strategies for regulation. Oxford: Clarendon Press. 
Bourne, L. S., \& Simmons, J. W. (Eds.) (1978). Systems of cities. New York: Oxford University Press.

Bunge, W. (1962). Theoretical geography. Lund: C. W. K. Gleerup.

Castells, M. (1996/2001). The rise of the network society. Oxford: Blackwell.

Christaller, W. (1933). Die zentralen Orte in Süddeutschland: Eine ökonomischgeographische Untersuchung über die Gesetzmäßigkeit der Verbreitung und Entwicklung der Siedlungen mit städtischen Funktionen. Jena: Gustav Fischer Verlag.

Christaller, W. (1933/1966). Central places in southern Germany (translated by C. W. Baskin). Englewood Cliffs, NJ: Prentice-Hall.

Christaller, W. (1950). Das Grundgerüst der räumlichen Ordnung in Europa: Die Systeme der europäischen zentralen Orte (Frankfurter Geographische Hefte, 24, 1). Frankfurt am Main: Kramer.

Christaller, W. (1966/1972). How I discovered the theory of central places: a report about the origin of central places. In: P. W. English \& R. C. Mayfield (Eds.), Man, space and environment (pp. 601-610). New York: Oxford University Press. 
Derudder, B., \& Taylor, P. J. (2018). Central flow theory: comparative connectivities in the world-city network. Regional Studies, 52(8), 1029-1040. https://doi.org/10.1080/00343404.2017.1330538

Doran, D., \& Fox, A. (2016). Operationalizing central place theory and central flow theory with mobile phone data. Annals of Data Science, 3(1), 1-24. https://doi.org/10.1007/s40745-015-0066-4

Friedmann, J. (1986). The world city hypothesis. Development and Change, 17(1), 69-83. https://doi.org/10.1111/j.1467-7660.1986.tb00231.x

Getis, A., \& Getis, J. (1966). Christaller's central place theory. Journal of Geography, 65(5), 220-226. https://doi.org/10.1080/00221346608982415

Glaeser, E. L., Ponzetto, A. M., \& Zou, Y. (2016). Urban networks: connecting markets, people, and ideas. Papers in Regional Science, 95(1), 17-59. https://doi.org/10.1111/pirs.12216

Hall, P. (2002). Christaller for a global age: redrawing the urban hierarchy. In A. Mayr, M. Meurer, \& J. Vogt (Eds.), Stadt und Region: Dynamik von Lebenswelten (pp. 110-128). Leipzig: Deutsche Gesellschaft für Geographie.

Hesse, M. (2013). Cities and flows: re-asserting a relationship as fundamental as it is delicate. Journal of Transport Geography, 29, 33-42.

https://doi.org/10.1016/j.jtrangeo.2012.12.014 
Hoyler, M. (2011). External relations of German cities through intra-firm networks - a global perspective. Raumforschung und Raumordnung, 69(3), 147159. https://doi.org/10.1007/s13147-011-0100-8

Jacobs, J. (1984). Cities and the wealth of nations. New York: Random House.

Jefferson, M. (1939). The law of the primate city. Geographical Review, 29(2), 226-232. https://doi.org/10.2307/209944

Mayhew, S. (2009). Central flow theory. In S. Mayhew (Ed.), A dictionary of geography (4th ed.). Oxford: Oxford University Press.

Ng, A. K. Y., Ducruet, C., Jacobs, W., Monios, J., Notteboom, T., Rodrigue, J.-P., Slack, B., Tam, K., \& Wilmsmeier, G. (2014). Port geography at the crossroads with human geography: between flows and spaces. Journal of Transport Geography, 41, 84-96. https://doi.org/10.1016/j.jtrangeo.2014.08.012

Parr, J. B. (1980). Frequency distributions of central places in southern Germany: a further analysis. Economic Geography, 56(2), 141-154. https://doi.org/10.2307/142932

Reclus, E. (1895). The evolution of cities. The Contemporary Review, 67(2), 246264. 
Reclus, E. (1905/2013). The history of cities. In J. Clark \& C. Martin (Eds.), Anarchy, geography, modernity: Selected writings of Elisée Reclus (pp. 163-185). Oakland, CA: PM Press.

Saey, P. (2008). The study of cities: historical and structural approaches. GaWC Research Bulletin, 276 https://www.lboro.ac.uk/gawc/rb/rb276.html.

Sassen, S. (1991/2001). The global city: New York, London, Tokyo. Princeton, NJ: Princeton University Press.

Taylor, P. J. (2001). Specification of the world city network. Geographical Analysis, 33(2), 181-194. https://doi.org/10.1111/j.1538-4632.2001.tb00443.x

Taylor, P. J. (2004). World city network: A global urban analysis. London: Routledge.

Taylor, P. J. (2007). Cities, world cities, networks and globalization. GaWC Research Bulletin, 238 https://www.lboro.ac.uk/gawc/rb/rb238.html.

Taylor, P. J. (2009). Urban economics in thrall to Christaller: a misguided search for city hierarchies in external urban relations. Environment and Planning A, 41(22), 2550-2555. https://doi.org/10.1068/a42235 
Taylor, P. J. (2012). On city cooperation and city competition. In B. Derudder, M. Hoyler, P. J. Taylor, \& F. Witlox (Eds.), International handbook of globalization and world cities (pp. 64-72). Cheltenham, UK: Edward Elgar.

Taylor, P. J. (2013). Extraordinary cities: Millennia of moral syndromes, worldsystems and city/state relations. Cheltenham, UK: Edward Elgar.

Taylor, P. J. (2019). City generics: external urban relations in ancientMesopotamian and modern-global city networks. Urban Geography, 40(8), 12101230. https://doi.org/10.1080/02723638.2019.1567203

Taylor, P. J., \& Derudder, B. (2016). World city network: A global urban analysis (2nd ed.). London: Routledge.

Taylor, P. J., Hoyler, M., \& Verbruggen, R. (2010). External urban relational process: introducing central flow theory to complement central place theory. Urban Studies, 47(13), 2803-2818.

https://doi.org/10.1177/0042098010377367

Thrift, N. (1986). The geography of international economic disorder. In R. J. Johnston \& P. J. Taylor (Eds.), A world in crisis? Geographical perspectives (pp. 1678). Oxford: Blackwell.

Ullman, E. (1941). A theory of location for cities. American Journal of Sociology, 46(6), 853-864. 
Van Meeteren, M., \& Poorthuis, A. (2018). Christaller and “big data”: recalibrating central place theory via the geoweb. Urban Geography, 39(1), 122-148.

https://doi.org/10.1080/02723638.2017.1298017

Verbruggen, R. (2011). World cities before globalisation: The European city

network, A.D. 1300-1600. Loughborough: Unpublished PhD thesis, Department of Geography, Loughborough University.

Xu, F.; Zhen, F., Qin, X., Wang, X., \& Wang, F. (2019). From central place to central flow theory: an exploration of urban catering. Tourism Geographies, 21(1), 121142. https://doi.org/10.1080/14616688.2018.1457076 
Table 1. The nature of Christaller's quantitative information.

Deductions (Table, p. 67):

Number of places

Number of service regions

Range of service region

Area of service region

Inductions:

(i) Informed guesstimate

Number of types of goods (illustrative approximation, p. 64 \& see pp. 140-141)

(ii) Collected data (Table p. 67 \& Table 1, p. 205)

Number of inhabitants (population)

Number of telephone connections

(iii) Derived (calculations)

Typical population of places (average from population data, p. 66 \& Table, p. 67)

Typical population of service region (average from population data, p. 66 \& Table, p. 67)

Telephone density (calculated from connections data, p. 147 \& Table 1, p. 205) 
Centrality (calculated from population and connections data, p. 147 \& Table 1, p. 205)

Determination:

Central types (ordinal measure from 'rough centrality', p. 150 \& Table 1 p. 205)

Note: All page references are to Baskin's translation (Christaller, 1933/1966). 
Table 2. Primate tendencies in Christaller's L-systems.*

\begin{tabular}{|c|c|c|c|c|}
\hline L-System & $\begin{array}{c}\text { L-city and } \\
\text { largest P-city }\end{array}$ & $\begin{array}{c}\text { Population } \\
\text { ratio }\end{array}$ & $\begin{array}{c}\text { Telephones } \\
\text { ratio }\end{array}$ & $\begin{array}{c}\text { Centrality** }^{* *} \\
\text { ratio }\end{array}$ \\
\hline Munich & $\begin{array}{l}\text { Munich \& } \\
\text { Augsburg }\end{array}$ & 4.1 & 7.8 & 12.6 \\
\hline Nuremberg & $\begin{array}{l}\text { Nuremberg \& } \\
\text { Würzburg }\end{array}$ & 4.7 & 5.3 & 5.5 \\
\hline Stuttgart & $\begin{array}{l}\text { Stuttgart \& } \\
\text { Pforzheim }\end{array}$ & 4.7 & 5.4 & 7.7 \\
\hline Frankfurt & $\begin{array}{l}\text { Frankfurt \& } \\
\text { Wiesbaden }\end{array}$ & 4.5 & 4.7 & 9.0 \\
\hline
\end{tabular}

* The Strasbourg L-system is not included because it does not have an L-city.

** Christaller uses this measure to indicate the importance of a place; it is defined by comparing telephone connections to population to show higher telephone densities (Christaller, 1933/1966, p. 147).

Note: The Baskin translation only provides data for the Munich L-system; the data used in this and subsequent tables are from the original publication (Christaller, 1933, pp. 263-325). 
Table 3. Telephone connections in Christaller's 5 L-systems.

\begin{tabular}{|l|c|c|c|c|c|c|c|c|c|c|}
\hline \multicolumn{1}{|c|}{ L-systems } & \multicolumn{2}{|c|}{ L-places } & \multicolumn{2}{|c|}{ P-places } & \multicolumn{2}{c|}{ G-places } & \multicolumn{2}{c|}{ B-Places } & \multicolumn{2}{c|}{ K-places } \\
\cline { 2 - 10 } & $\mathrm{N}$ & Ave. & $\mathrm{N}$ & Ave. & $\mathrm{N}$ & Ave. & $\mathrm{N}$ & Ave. & N & Ave. \\
\hline Munich & 1 & 5029 & $2(1)$ & 648 & $8(6)$ & 89 & 18 & 33 & 59 & 12 \\
Nuremberg & 1 & 2623 & 2 & 429 & 10 & 117 & 23 & 31 & 60 & 11 \\
Stuttgart & 1 & 2853 & 2 & 417 & 8 & 143 & 33 & 43 & 73 & 14 \\
Frankfurt & 1 & 4210 & $4(3)$ & 659 & $8(6)$ & 170 & 12 & 47 & 47 & 14 \\
\hline
\end{tabular}

Note: Averages are for German cities only; where they are less than the total their number is given in brackets. $1=10$ telephone connections.

Data: Calculated from Christaller (1933, pp. 263-325), based on official telephone directories issued for Germany between the end of March and August 1931, and for the Saar region in November 1930. 
Table 4. Comparing change coefficients between service levels.

(i) THEORY $(\mathrm{k}=3)$

\begin{tabular}{|c|c|c|c|c|}
\hline $\begin{array}{c}\text { Service } \\
\text { level }\end{array}$ & Market & Total & Adjacent & Change \\
market & levels & coefficients \\
\hline K & 400 & 400 & - & - \\
G & 1200 & 1600 & B/K & 4 \\
P & 10800 & 16000 & P/G & 3.25 \\
L & 32400 & 48400 & L/P & 3.03 \\
\hline
\end{tabular}

(ii) EMPIRICS (Telephone connections in L-systems)

\begin{tabular}{|c|c|c|c|c|c|}
\hline \multirow{2}{*}{ Adjacent } & \multicolumn{5}{|c|}{ Telephone connection change coefficients } \\
\cline { 2 - 6 } & Munich & Nuremberg & Stuttgart & Frankfurt & Average \\
\hline B/K & 2.75 & 2.82 & 3.07 & 3.36 & 3.00 \\
G/B & 2.70 & 3.77 & 3.33 & 3.62 & 3.36 \\
P/G & 7.28 & 3.67 & 2.92 & 3.88 & 4.44 \\
L/P & 7.76 & 6.11 & 6.84 & 6.39 & 6.78 \\
\hline
\end{tabular}


(iii) DIFFERENCE (between change coefficients)

\begin{tabular}{|c|c|c|c|}
\hline $\begin{array}{c}\text { Adjacent } \\
\text { levels }\end{array}$ & $\begin{array}{c}\text { Observed } \\
\text { (average) }\end{array}$ & $\begin{array}{c}\text { Predicted } \\
\text { (market) }\end{array}$ & Difference \\
\hline B/K & 3.00 & 4.00 & -1.00 \\
G/B & 3.36 & 3.25 & 0.11 \\
P/G & 4.44 & 3.08 & 1.36 \\
L/P & 6.78 & 3.03 & 3.75 \\
\hline
\end{tabular}


Table 5. Deriving telephone connections in L-places for central flow theory.

\begin{tabular}{|c|c|c|c|c|c|c|}
\hline \multirow[b]{2}{*}{ L-systems } & \multicolumn{2}{|c|}{ EMPIRICAL } & \multicolumn{2}{|c|}{$\begin{array}{c}\text { CENTRAL PLACE } \\
\text { THEORY }\end{array}$} & \multicolumn{2}{|c|}{$\begin{array}{c}\text { CENTRAL FLOW } \\
\text { THEORY }\end{array}$} \\
\hline & $\begin{array}{l}\text { Actual } \\
\text { telephone } \\
\text { connections } \\
\text { for L-places }\end{array}$ & $\begin{array}{l}\text { Average } \\
\text { telephone } \\
\text { connectio } \\
\text { ns for K- } \\
\text { places }\end{array}$ & $\begin{array}{l}\text { Predicted } \\
\text { telephone } \\
\text { connections } \\
\text { for L- } \\
\text { places* }\end{array}$ & $\begin{array}{l}\text { Percentage } \\
\text { of actual } \\
\text { telephone } \\
\text { connections }\end{array}$ & $\begin{array}{l}\text { Difference } \\
\text { between } \\
\text { predicted } \\
\text { and actual }\end{array}$ & $\begin{array}{l}\text { Percentage } \\
\text { of actual } \\
\text { telephone } \\
\text { connections }\end{array}$ \\
\hline Munich & 5029 & 12 & 1452 & 29 & 3577 & 71 \\
\hline Nuremberg & 2623 & 11 & 1331 & 51 & 1292 & 49 \\
\hline Stuttgart & 2853 & 14 & 1694 & 59 & 1159 & 41 \\
\hline Frankfurt & 4210 & 14 & 1694 & 40 & 2516 & 60 \\
\hline
\end{tabular}

* The prediction is the average for K-places multiplied by the market multiplier from K-places to L-places. This is derived from Table 4 as 48,400/400 $=121$. 


\section{NOTES}

${ }^{1}$ Christaller did devise a settlement pattern based upon transport $(\mathrm{k}=4)$ but this was a specific arrangement. We focus on his market derived settlement pattern $(\mathrm{k}=3)$ as a general economic process. Similarly there are studies of specific nonlocal urban relations featuring, for example, port cities and gateway cities (see Hesse, 2013; Ng et al., 2014), but we focus on overall inter-city relations in networks, central flow theory.

${ }^{2}$ Christaller (1933/1966, p. 171) briefly returned to the spacing of cities in his regional descriptions. He identifies 'L-Directions Lines' between major cities as a simple spatial exercise: two short paragraphs, one on distances between cities and the other on angles between the lines. This is not related to his theoretical arguments.

${ }^{3}$ In fact we can connect Christaller's 'sub-national' settlement systems approach to Jacobs' (1984, pp. 31-32) view that states are political entities and do not define economic process. Rather they consist of 'collections' of economies. Treating the latter as Christaller's L-systems, when aggregating to the national scale it is likely that rank-size patterns are created from the differences between regional primate cities. This is why, in Berry's (1961) analyses, it is the larger countries that have rank-size settlement 'state-istical' outcomes.

${ }^{4}$ For instance, in Christaller (1933/1966, p. 204) there are histograms showing the frequency distributions of all five L-systems based upon the 'centrality number' of settlements (derived from telephone connections). However, the graphs only show the bottom five hierarchical levels: $M, A, K, G$, and B. Levels $P$ and $\mathrm{L}$ are not included because the settlements are so much larger. Thus to 
include Munich on the histogram would require the addition of more than 50 pages to complete the histogram (the published graph ends on 51, Munich's number is 2,825$)$.

5 Batty (2013, pp. 25-26) directly addresses the 'openness' of systems of cities but treats it in a different manner to that pursued in this paper: systems are viewed as existing in a volatile environment to be dealt with through complexity theory and new types of geometry. 